\title{
The Reality of Applying BSC Approach and the Obstacles to Its Application in Islamic Banks in Palestine
}

\author{
Raed Abueid \\ Al-Quds Open University, Palestine \\ E-mail: rabueid@qou.edu
}

\begin{abstract}
The research aimed to recognize the reality of the application of the Balanced Scorecard (BSC) Approach and the Obstacles applied in the Islamic banks in Palestine. The researcher has designed a questionnaire composed of two dimensions, then the questionnaire was distributed to male and female employees in Islamic banks operating in the Hebron district, Data were statistically analyzed by the SPSS program, The study concluded that the reality of the application of Balanced Scorecard Approach in Islamic banks was High in general on all dimensions of the study, and that the most important obstacles to the application of the Balanced Scorecard (BSC)Approach in these banks are the lack of knowledge of these banks and the benefits of the application of this approach, In addition to the high cost of implementation and the lack of qualified personnel to implement it, The study recommended the need for attention and increase Islamic banks in focusing on the application of this approach because of its advantages which are beneficial to the banks, customers and the community in general and its adoption in the marketing strategies, and that Islamic banks should work to intensify its efforts to develop and improve banking services to keep up with developments in the world.
\end{abstract}

Keywords: Financial Dimension, Customer Dimension, Internal Processes Dimension, Learning and Growth Dimension, Islamic Banks.

\section{Introduction}

The idea of " What can be measured can be managed" has been discussed among administrative professionals. This statement was the first beginnings of the concept of institutional measurement, on which institutions rely on the evaluation of their overall strategy and used many measures (Abu Fadda, 2006).

In the I980s, a set of administrative concepts emerged to monitor processes in organizations such as: Total Quality Management (TQM), cost measurement based on activity ABC, etc., but these tools focus on financial aspects and did not address non-financial aspects. In 1990 the Balanced Scorecard (BSC) founded which covers the financial and non-financial aspects of organizations with an integrated and comprehensive view of organizations (Morisawa, 2002).

As financial indicators address past and present performance, organizations have been developing and innovating leading indicators and these indicators taking into account customers and operational processes and the need for innovation and continuous improvement, providing a more balanced approach because balance is necessary to move efficiently and effectively to achieve desired goals (Chaudron, 2003).

As the global crisis has shown the strength of Islamic banks, which have led to the bankruptcy of many conventional banks in America, Europe and others, Islamic banks have been able to achieve continuous growth of more than $20 \%$ per annum since 2000 and achieve financial dealings away from usury and profit and loss And the use of Islamic investment tools with customers in accordance with the provisions of Islamic law and in a manner contrary to the philosophy of commercial banks (Salama, 2002; Ali, 2005).

Therefore, as Islamic banks play an important role in economic life, they seek to apply everything new in the field of banking services, in line with developments in the world and in accordance with the provisions of Islamic Shariah in all bank ing services provided to customers. Business is primarily about knowing its customers or clients, identifying their purchasing characteristics and behavior and analyzing the factors influencing them, in order to re-formulate their marketing strategies for banking services, in order to attract customers and gain customer confidence.

\section{Research Problem and Questions}

The problem of the study is to identify the reality of the application of BSC approach and obstacles in Islamic banks in Hebron governorate. The researcher formulated the problem of the study with the sub-questions:

- What is the reality of implementing the financial dimension of BSC in the Islamic banks operating in Hebron governorate? 
- What is the reality of applying the customer dimension of BSC in the Islamic banks operating in Hebron governorate?

- What is the reality of the application of internal processes dimension of BSC in the Islamic banks operating in Hebron governorate?

- What is the reality of applying the learning and growth dimension of BSC in the Islamic banks operating in Hebron governorate?

- What are the obstacles facing the Islamic banks in applying BSC approach?

\section{Research Objectives}

The researcher defined the objectives of this research as follows:

- Identify the reality of the application of the Islamic banks in the Hebron governorate the Balanced Scorecard (BSC) which is (financial dimension, customer dimension, dimension of internal processes, education and growth dimension).

- Highlighting the obstacles faced by Islamic banks in the Hebron governorate in implementing the BSC

- Studying the level of the effect of demographic variables such as gender, scientific qualification, and the bank on the reality of applying balanced performance in Islamic banks?

- To develop some recommendations on the implementation of BSC in the Islamic banks operating in Hebron governorate in order to improve and develop them.

\section{Research Importance}

The importance of research stems from the parties that will benefit from it:

- The importance of theoretical research is through the study of books and studies that dealt with the subject of Balanced Performance Approach (BSC) in organizations in general and Islamic banks in particular research and study in order to fill scientific research to assist researchers and interested in this field.

- The scientific importance of this research is reflected in the role played by the BSC and its impact on Islamic banks, in light of its findings and recommendations. It is hoped that Islamic banks in general and the Palestinian Islamic Bank and the Arab Islamic Bank will benefit in particular. By applying the findings and recommendations of the research.

- This research aims to clarifying the importance of applying BSC in Islamic banks and improving and developing the services provided to meet the wishes and needs of its clients, and to identify the strengths and weaknesses in the service as well as to avoid the deficiencies and negligence resulting from lack of human perception or deliberate .

\section{Theoretical Framework and Literature Review}

The BSC approach was discovered by American researchers Kaplan and Norton in 1992 from Harvard University, where they tested this approach on 12 major US companies to determine the requirements of managers for performance adequacy meas ures in these companies (Kaplan \& David, 1992).

Fortune magazine reported that 70 percent of the 1,000 companies in the world use a BSC approach. The Harvard Business Journal saw the BSC approach as the most effective.

Balanced Scorecard (BSC): A set of metrics that give senior management a quick and comprehensive picture of business that includes financial metrics that report the results of specific activities and their integration with operational metrics of customer satisfaction, internal processes and creativity, and improvement of the organization's activities (Kaplan \& David, 1992)

Islamic Bank: is a banking institution whose purpose is to collect funds and savings from individuals and institutions and then to employ them in various economic activities and to provide various banking services to clients in accord ance with the provisions of Islamic law (Mubarak \& Yunis, 1996).

\section{I The Importance of Applying BSC Approach}

- Provide managers with indicators of cause and outcome indicators of their organizations.

- Setting benchmarks in the BSC approach is the fundamental motivation for the organization's strategic objectives and competitive requirements.

- Through the dimensions of this approach organizations will be able to monitor financial results while monitoring progress in building capacity and acquiring intangible assets.

- 4 - Work to create a correlation between goals and performance measures.

- The BSC approach provides a comprehensive picture of the nature of the operations of the various operations occurring within the Organization (Zhang \& Li, 2009). 


\subsection{BSC Dimensions}

- Financial Dimension: The organization's strategic profitability is measured because the cost reduction for competitors and others is a key strategic initiative of the organization. This aspect depends on how much operating income and return on capital will be employed as a result of cost reduction and the sale of more units of the organization's products.

- Customer dimension: It is concerned with the way that creates value for customers and customer satisfaction, and why he will be willing to pay more. This dimension guides internal processes and attempts at institutional development. This dimension uses indicators such as number of customers and customer satisfaction.

- Internal processes dimension: This dimension depends on internal processes that achieve both customer satisfaction by creating value for customers which is a critical and sensitive point for the enterprise.

- Learning and Growth dimension: Learning and growth in institutions is achieved through efficient work teams, positive thinking and a broad understanding of the nature of the organization's presence in its environment, learning indicators and growth, labor turnover, average years of employee service (Berkman, 2007).

- Social dimension: This dimension focuses on the development of society and attention to its requirements because the support of the community is a national duty on business organizations, through the support of social, health and educational activities and contribute to solving housing problems, etc., and diversification in its services to society (Abu Faddah , 2006).

- Shari'ah Supervisory Control dimension: the Shari'ah Supervisory Officer, and the Internal Shari'ah Supervisory Officer, which contains a specific and disciplined number of standards, which include achieving a fair profit, focuses on achieving Halal profit in the institution and committing to avoid illicit sales, Which revolves around the banking operations that are being implemented on the ground, as well as avoid investment formulas that are forbidden by law and are committed to investment activities, which is the justification for the presence of Islamic banks (Abbadi, 2002).

Zoelf \& Noor (2005) study aimed to showing the importance and extent of using the Balanced Scorecard in evaluating strategic performance in the Jordanian banking sector in 2005. The study concluded the following results: Balanced Scorecard is the most suitable for measuring performance, there is also a link between the four standards and the strategy of the organization. The four performance measures vary from one organization to another and from one department to another in the same establishment according to the nature of the activities.

Abu Fadda (2006)The study concluded the importance of building BSC measurement models in general and strategic performance in particular, thus developing the traditional system by adding the ideological dimension and Islamic intellectual, and adding the two dimensions which embody the dimension of contract And intellectual adaptation, and adapting the system to comply with Islamic banking institutions, after studying the strategy with all its elements and detailed research in the theoretical framework to build a system of performance measurement and characteristics of the nature of Islamic banks.

Abu Qamr (2009) study concluded that the management of Bank of Palestine exercises strategic management and does not apply the BSC approach. The Bank of Palestine contributes to the support of the society but its interest The social dimension was not as important as the other dimensions, and the bank offers superior banking services to its clients that exceed those offered by competitors.

Dargham \& Abufadda (2009) study concluded that the BSC approach can be used in its four dimensions in order to enhance the strategic financial performance of the Palestinian banks operating in the Gaza Strip. Banks have a clear perception of the dimensions of strategic financial performance, which enables them to achieve strategic financial performance.

Azaizia (2010) study concluded that the obstacles of implement BSC is not knowing the importance of application and the costs of implementing a balanced scorecard and the lack of qualified human resources to apply the Balanced Scorecard in Commercial banks and also showed that there is no impact of the absence of a belief in the importance of non-financial measures on the use of the balanced scorecard in the Jordanian commercial banks.

Ahmad (2010) prepared a study aimed to identifying the awareness of specialists in the banking business with the BSC approach and the extent to which the commercial, Islamic and foreign banks operating in Pakistan have implemented this approach in their daily operations. The study concluded that $16 \%$ of respondents know about BSC approach, and $95 \%$ of respondents use this approach to evaluate the performance in banks, but it is used spontaneously without the knowledge that they apply this approach, and it was found that there is consensus on the need to add new items on this approach to fit With the work of all banks.

Al-Dhibeh (20II) study also concluded that the Yemeni commercial banks implement the BSC approach of four dimensions: financial, customers, internal processes, learning and growth and recommended the Yemeni commercial banks to 
add the customer dimension within the criteria of the strategy of performance to be able to keep the banks in the comparative position with the global banks.

Abu Gazer (2012) He also conducted a study aimed to identifying the extent of using the BSC as a tool to evaluate the performance of the Islamic Bank of Palestine. He also found that there is a positive effect on all dimensions of the BSC approach on the bank's performance to varying degrees. And banking services provided were lower than expected by customers.

Al-Gareeb \& Abu Ajila (2012) study aimed to identifying the extent to which a balanced scorecard can be used to evaluate the performance of Libyan commercial banks, the study found that Libyan commercial banks have full stability to implement a balanced scorecard and all the necessary data are available for implementation and integration of accounting and administrative systems.

Dave (2012) Conducted a study that aimed to applying the BSC approach in the Indian banking sector , and the study apply the BSC approach to the Indian state bank, where the use of bank data during the period 1997-2008, was also used 29 index to measure the performance of the bank, the results showed that the performance of the bank in the financial dimension it was high, either on customers have found a little variation, and internal processes, it has been shown that the percentage of wages in recent years tend to decline, and a paragraph of staff earnings are continuing with an increase, and finally learning and development has found a significant evolution in good use of technology and Training staff.

AL-Najjar \& Khalaf (20I2) study was designed to evaluate the performance of the large local bank in Iraq for the period 2006-2009 through the BSC approach, They found that the Bank's financial performance during the three years was weak and the internal operations did not show improvements, The dimension of customers was the worst because some of customers withdraw their money from Iraq because it is not safe, but in the field of learning and development was better than customers dimension, but he did not open new branches in Iraq because of security conditions.

Dave (2012) study was aimed to implement the BSC approach in the State Bank of India, The Bank's data were used during the period from 1997 to 2008, and 29 indicators were used to measure the Bank's performance. The results showed that the Bank's performance in the financial dimension was high, As for the customers, there was little variation and the internal operations dimension it was found that the percentage of wages in recent years is going down, And on the earnings of employees there is a continuous increase in them, and finally learning and development has found a great development and well in the use of technology and training staff.

Nik et al. (2013)They prepared a study whose aim was to identify the structure of the BSC approach and its possible application in Malaysian Islamic banks. The study found that six Malaysian Islamic banks fully implement the BSC approach. The results also show that banks apply the BSC approach directly or indirectly.

Ombuna et al. (2013) Where they conducted a study aimed to examine the effect of using the BSC approach on the performance of commercial banks in Kenya. The study was conducted on I8 banks in Kenya and concluded that the use of this approach has a positive effect on the performance of commercial banks in Kenya. To achieve and implement the vision and strategies and provide feedback on internal processes and external outcomes for continuous improvement of results and strategic performance.

Salamat \& Ghadikalaei (2014) They conducted a study to assess the performance of employees at Iandh Bank in Tehran using the BSC approach, . The study concluded that the Bank's performance was positive in terms of the four dimension of BSC approach, namely, learning and growth, customers, and the financial dimension and internal processes.

Rostami et al. (2015) study found that the customers ranked first and then came the financial dimension in the order and second is followed by internal processes in the third order and finally learning and growth.

Through the review of previous studies the researcher find that some of these studies focused on the use of this approach in commercial banks with four dimensions identified by Kaplan, Norton, Therefore, this study meets with the previous studies in the study of the uses of the BSC approach in the banks and also meets with each other in the research tool used, and differs from it in that this study touched on an important door, knowing the extent and reality of using this portal in Islamic banks in Palestine Without applying this approach in Islamic banks. It is also an important addition to the Islamic banks to take care of this approach because it evaluates the work of Islamic banks in all aspects and financial and non-financial dimensions. Islamic banks can also develop banking services in line with the technological developments in the world and marketing strategies because they will also increase their market share.

\section{Research Methodology}

The researcher used the analytical descriptive method, which is based on the study of the phenomenon as it exists in fact and is concerned as a precise description; the quantitative expression gives a numerical description of the size and degrees of the phenomenon, and the degree of its correlation with other phenomena. This approach does not only depend on the collection of information but rather on analysis, linkage and interpretation to reach conclusions based on the perception Proposed. 


\section{I Population and Sample}

The research population consists of all the employees of the Islamic banks working in the Hebron governorate (Palestinian Islamic Bank and the Arab Islamic Bank). Therefore, the survey method was used and (55) questionnaires were distributed to all employees in these branches.

\subsection{Research Tool}

The researcher used the questionnaire as a means of collecting data. After reviewing the number of previous studies and the tools used and the theoretical literature on the subject of the study and its objectives, the researcher developed a special questionnaire to identify the reality of the application of Islamic banks to BSC approach and obstacles. The researcher was guided by some questions from the previous questionnaires, and he relied mainly on the questionnaire (Al-Dhibeh, 20I I; Abu-Gazer, 20I2; AlGareeb, 2012). After the reformulation of some of the questions and modified to be appropriate and suitable for research purposes.

The questionnaire was designed on the basis of the Likert Scale. The researcher used his knowledge of the previous studies in his interpretation of the results and analyzed the following grades:

- If the arithmetic mean is less than or equal to 2.50, the application status is low.

- If the arithmetic mean is greater than $2.5 \mathrm{I}$ and less than 3.50, the application is moderate

- If the arithmetic mean is greater than 3.5I, the application is high.

\subsection{Research Variables}

The search includes the following variables:

- Independent variable: It includes the following variables: BSC dimensions: financial dimension, Customers dimension, Internal processes dimension, learning and growth dimension, Social dimension and Shari'ah Supervisory Control dimension.

- The dependent variable: the reality of application of the BSC dimensions and the obstacles' of its application in Islamic banks. SPSS used in the analysis of results.

\section{Results and Discussion}

\section{I Characteristics of Demographic Sample}

The researcher distributed (55) questionnaires to the employees of the Palestinian Islamic Bank (Wad Al-Tuffah Branch, Ras Al-Jura Branch) and the Arab Islamic Bank (Hebron Branch, Yatta Branch). The questionnaire was collected after filling (49) the questionnaire was retrieved and the questionnaires were sorted of the response conditions and the questionnaire was (48) excluded (I) because it was not valid for statistical analysis.

Table(I) shows the reality of applying BSC approach in the Islamic banks operating in the Hebron governorate, which was generally high on all dimensions of the study with an mean(4.03), financial Dimension is the first level with an mean(4.22), While dimension learning and growth ranked last with mean(3.85).

The results differed with the study of (Al-Dhibeh, 20I I; Dargham \& Abufadda, 2009; Zoelf \& Noor , 2005; Salamat $\&$ Ghadikalaei, 2014).

TableI. Employees working in the Hebron governorate ranked as important

\begin{tabular}{llll}
\hline Dimensions & the number & Mean & standard deviation \\
\hline Shari'ah Supervisory Control dimension & 48 & 4.47 & 0.6 \\
\hline financial Dimension & 48 & 4.22 & 0.43 \\
\hline Customer dimension & 48 & 4.04 & 0.48 \\
\hline Internal processes dimension & 48 & 4.03 & 0.52 \\
\hline learning and growth dimension & 48 & 3.85 & 0.56 \\
\hline Social dimension & 48 & 3.57 & 0.58 \\
\hline Total score & 48 & 4.03 & 0.35 \\
\hline
\end{tabular}

Question I: What is the reality of applying BSC approach of the financial dimension in the Islamic banks working in the governorate of Hebron?

Table (2) shows that the reality of implementing the financial dimension in the Islamic banks working in the Hebron governorate was high, where a paragraph was obtained that seeks to maximize the wealth of shareholders and depositors by achieving real returns on investment at the highest mean (4.46) The percentage of profits distributed to shareholders commensurate with their expectations of the lowest mean (3.7I). 
Table 2. The reality of application of the BSC approach of financial dimension in the Islamic banks working in Hebron governorate ranked by importance

\begin{tabular}{|c|c|c|c|}
\hline \multicolumn{4}{|l|}{ First dimension: financial dimension } \\
\hline Paragraph & the number & mean & Std.deviation \\
\hline $\begin{array}{l}\text { The Bank's management seeks to maximize the wealth of shareholders and } \\
\text { depositors by achieving real returns on investment }\end{array}$ & 48 & 4.46 & .683 \\
\hline The profitability standard is achieved through diversity in customer services & 48 & 4.42 & .577 \\
\hline $\begin{array}{l}\text { The Bank's management works to balance cash management, assets and } \\
\text { working capital to maintain shareholders' equity }\end{array}$ & 48 & 4.33 & .595 \\
\hline Achieving fair profit is a strategic goal achievable in the bank & 48 & 4.27 & .707 \\
\hline $\begin{array}{l}\text { The balanced growth standard of the income mix is the core investment } \\
\text { activity implemented by the Bank }\end{array}$ & 48 & 4.19 & $.57 \mathrm{I}$ \\
\hline $\begin{array}{l}\text { The percentage of dividends distributed to shareholders commensurate with } \\
\text { their expectations. }\end{array}$ & 48 & $3.7 \mathrm{I}$ & .898 \\
\hline
\end{tabular}

Question 2: What is the reality of applying BSC approach of the customers dimension in the Islamic banks working in the governorate of Hebron?

Table (3) shows that the reality of application customers dimension in the Islamic banks operating in Hebron governorate was high. The Bank applies the criterion of retaining customers by increasing the volume of transactions and communicating with them continuously at the highest of the mean (4.44) while a paragraph evaluates the Bank's standard of retaining customers by the number of customers who left the bank to deal with the lowest mean (3.58).

Table 3. Mean and the standard deviations of the reality of application of the customer dimension in the Islamic banks working in Hebron governorate ranked by importance in the second dimension:

\begin{tabular}{|c|c|c|c|}
\hline \multicolumn{4}{|l|}{ Second dimension: customers dimension } \\
\hline Paragraph & $\begin{array}{l}\text { the } \\
\text { number }\end{array}$ & Mean & Std.deviation \\
\hline $\begin{array}{l}\text { The Bank applies the customer's retention standard by increasing the volume of } \\
\text { transactions and communicating with them continuously. }\end{array}$ & 48 & 4.44 & .580 \\
\hline $\begin{array}{l}\text { Customer's loyalty is obtained through the provision of banking services in the shortest } \\
\text { possible time and response to the treatment of customer's complaints. }\end{array}$ & 48 & 4.23 & $.75 \mathrm{I}$ \\
\hline The time spent providing the service is commensurate with the normal time of the service. & 48 & 4.17 & .630 \\
\hline $\begin{array}{l}\text { The Bank applies the fair market share standard, which balances the available regulatory } \\
\text { capacity with the target market share. }\end{array}$ & 48 & 4.02 & .729 \\
\hline $\begin{array}{l}\text { The Bank practices the standard of profitability of the client through achieving a fair and } \\
\text { satisfactory profit for him. }\end{array}$ & 48 & 3.85 & .684 \\
\hline $\begin{array}{l}\text { The Bank maintains a customer's retention standard through the number of customers } \\
\text { who have left the Bank. }\end{array}$ & 48 & 3.58 & 1.007 \\
\hline
\end{tabular}

Question 3: What is the reality of applying BSC approach of the internal processes dimension in the Islamic banks working in the governorate of Hebron?

Table (4) shows that the reality of implementation of the internal processes in the Islamic banks operating in the Hebron governorate was high. The Bank always sought to develop and improve the services and skills of the employees and information technology in the bank at the highest mean (4.35) the efficiency criterion in addressing the available resources which determines the level of utilization of the available capacity at the lowest mean (3.8I). 
Table 4.The mean and the standard deviations of the reality of application of the internal processes dimension in the Islamic banks working in Hebron governorate ranked by importance in the third dimension:

\begin{tabular}{lcc}
\hline Third Dimension: internal processes dimension & $\begin{array}{l}\text { the } \\
\text { number }\end{array}$ & mean \\
\hline Paragraph & 48 & 4.35 \\
\hline $\begin{array}{l}\text { The Bank is always seeking to develop and improve the services, staff skills and information } \\
\text { technology of the Bank. }\end{array}$ & .785 \\
\hline $\begin{array}{l}\text { The standard of mastering and providing the service applied in the bank competes with global } \\
\text { standards. }\end{array}$ & 48 & 4.00 \\
\hline $\begin{array}{l}\text { The Bank practices the standard of productivity by meeting the needs of customers, which } \\
\text { makes the service of a desirable quality. }\end{array}$ & 48 \\
\hline $\begin{array}{l}\text { The Bank applies the efficiency standard in the treatment of available resources, which } \\
\text { determines the level of utilization of available capacity. }\end{array}$ & 48 & 3.96 \\
\hline
\end{tabular}

Question 4: What is the reality of application learning and growth dimension in the Islamic banks operating in Hebron Governorate?

Table (5) shows that the reality of application learning and growth dimension in the Islamic banks working in Hebron governorate was high, where a paragraph was obtained that provides the Bank with the appropriate educational skills in individuals at the highest mean (4.06), While the Bank has achieved a standard of profitability of the employee by achieving a fair profit through its ability to achieve economic value of the bank at the lowest mean (3.7I).

Table 5. The mean and standard deviations of the reality of applying learning and growth dimension in the Islamic banks working in Hebron governorate ranked by importance

\begin{tabular}{|c|c|c|c|}
\hline Fourth Dimension: learning and growth dimension & & & \\
\hline Paragraph & $\begin{array}{l}\text { the } \\
\text { number }\end{array}$ & mean & Deviation \\
\hline The Bank provides appropriate educational skills to individuals & 48 & 4.06 & .665 \\
\hline The Bank has a high percentage of employees with excellent practical experience & 48 & 4.04 & .713 \\
\hline $\begin{array}{l}\text { The Bank practices the employee satisfaction standard by meeting the needs of } \\
\text { employees and commensurate with their abilities and qualifications }\end{array}$ & 48 & 3.83 & .859 \\
\hline The Bank applies the retention criteria by satisfying its material, moral and legal needs & 48 & 3.79 & .849 \\
\hline Staff in the bank stick to their jobs and do not seek another alternative. & 48 & $3.7 \mathrm{I}$ & .824 \\
\hline $\begin{array}{l}\text { The Bank practices the employee's profitability by achieving a fair profit through its } \\
\text { ability to achieve economic value of the Bank }\end{array}$ & 48 & $3.7 \mathrm{I}$ & .743 \\
\hline
\end{tabular}

Question 5: What is the reality of applying the social dimension in the Islamic banks working in Hebron governorate?

Table (6) shows that the reality of applying the social dimension in the Islamic banks operating in the Hebron governorate was high, where a paragraph was obtained that provides the bank with support for people with special needs at the highest average (3.79), while a paragraph contributes to the establishment of hospitals, The lowest mean (3.23). 
Table 6. Means and standard deviations of the reality of applying the social dimension in the Islamic banks working in Hebron governorate ranked by importance

\begin{tabular}{|c|c|c|c|}
\hline \multicolumn{4}{|l|}{ Fifth Dimension: social processes dimension } \\
\hline Paragraph & $\begin{array}{l}\text { the } \\
\text { number }\end{array}$ & mean & Deviation \\
\hline The Bank provides support to people with special needs & 48 & 3.79 & .683 \\
\hline The bank helps students complete their studies and educational careers & 48 & 3.73 & .984 \\
\hline $\begin{array}{r}\text { The Bank provides support for cultural, practical and recreational activities for the } \\
\text { community }\end{array}$ & 48 & 3.65 & .601 \\
\hline The Bank contributes to solving the problem of unemployment by creating job opportunities & 48 & 3.48 & .743 \\
\hline The Bank contributes to the establishment of hospitals, universities and schools & 48 & 3.23 & $.88 \mathrm{I}$ \\
\hline
\end{tabular}

Question 6: What is the reality of application of the controls of legal transactions dimension in the Islamic banks working in Hebron?

Table (7) shows that the reality of application of the controls of Islamic transactions dimension in the Islamic banks working in the Hebron governorate was high, where there was a paragraph that avoids the bank to deal with interest and take interest at the highest mean (4.6). The Audit and Auditing Organization for Islamic Financial Institutions has the lowest mean (4.37).

Table 7. Means and standard deviations of the reality of applying the controls of legal transactions dimension in the Islamic banks working in Hebron governorate ranked by importance

\begin{tabular}{|c|c|c|c|}
\hline Sixth Dimension: the controls of legal transactions dimension & & & \\
\hline Paragraph & $\begin{array}{l}\text { the } \\
\text { number }\end{array}$ & mean & Deviation \\
\hline The Bank avoids dealing with interest bearing interest & 48 & 4.60 & .610 \\
\hline $\begin{array}{l}\text { The Shari'ah Supervisory Board ensures that the Bank complies with its legal obligations in all } \\
\text { banking transactions }\end{array}$ & 48 & 4.50 & .968 \\
\hline The Bank applies the principle of good morals in dealing with employees and customers & 48 & 4.48 & $.7 \mathrm{I} 4$ \\
\hline Banking operations conducted in the bank are free from legally prohibited sales 484.40 .676 & 48 & 4.40 & .676 \\
\hline $\begin{array}{l}\text { The Bank shall apply the rules and standards prescribed by the Audit and Auditing } \\
\text { Organization for Islamic Financial Institutions }\end{array}$ & 48 & 4.37 & $.98 \mathrm{I}$ \\
\hline
\end{tabular}

In the opinion of the researcher that the occupation of the controls of legal transactions dimension is the first order is the result of that these banks have a body of fatwa Shari'ah and it monitors the legitimacy of all banking process that take place in these banks to comply with the provisions of Islamic law, and differed with the study (Abu Qmar, 2009). The results of the study (Rostami et al., 2015) which were the result of occupation after the first order customers also differed with the study (ALNajjar \& Khalaf, 2012) the financial dimension was weak.

It was also agreed with the study of (Abu-Gazer, 2012; Nik et al., 2013) that banks apply the BSC approach in a spontaneous manner without their knowledge. (Ombuna et al., 2013). The application of this portal provides feedback on internal processes and external outcomes for continuous improvement of banking services and in line with international standards. 
Question 7: What are the obstacles to the implementation of the BSC approach in Islamic banks operating in Hebron?

Table (8) shows that the obstacles to applying the BSC approach in the Islamic banks working in the Hebron governorate were moderate. The bank's lack of knowledge of the advantages of implementing the BSC approach was obtained in the highest (3.29) and the lack of competencies. Analyze data to apply This approach is at lowest mean (2.94).This result is explained by the researcher that there is not enough awareness among the Islamic banks of the importance of applying this approach and its advantages, which will lead to the lack of qualified human resources to implement it.

Table 8. Mean and the standard deviations of the obstacles to applying BSC approach in the Islamic banks operating in the Hebron governorate are arranged according to the importance in this field:

\begin{tabular}{|c|c|c|c|}
\hline \multicolumn{4}{|l|}{ The second section: Obstacles to the implementation of the BSC approach in Islamic banks } \\
\hline Paragraph & $\begin{array}{l}\text { the } \\
\text { number }\end{array}$ & mean & Std.deviation \\
\hline The Bank does not know the advantages of applying the BSC Approach & 48 & 3.29 & I.03I \\
\hline The cost of implementing this approach is high & 48 & 3.27 & .792 \\
\hline Lack of financial resources to implement this approach & 48 & 3.17 & .883 \\
\hline $\begin{array}{l}\text { The complexity of the system applied in the bank prevents the application of this } \\
\text { approach }\end{array}$ & 48 & 3.17 & .907 \\
\hline The inability to keep pace with the technological developments in this approach & 48 & 3.12 & .866 \\
\hline Lack of willingness of employees in the bank to change & 48 & 3.08 & .986 \\
\hline $\begin{array}{l}\text { Lack of competencies capable of compiling and analyzing data to implement this } \\
\text { approach }\end{array}$ & 48 & 2.94 & .932 \\
\hline
\end{tabular}

This result was agreed with the study of (Azaizia, 2010) that there are obstacles that prevent the application of this approach in banks including lack of knowledge of the importance of its application in addition to the lack of financial resources to implement this approach.

\section{Recommendations}

- Attention should be given to increasing the concentration of Islamic banks on the application of the BSC approach because of the advantages that benefit the banks, customers and society in general and adopt it among its marketing strategies.

- Islamic banks should intensify their efforts to spread the culture of this approach among their employees holding courses, seminars and training programs to qualify them because this will reflect on the development and improvement of banking services.

- The researcher recommends Islamic banks to work to remove obstacles in the application of this approach by developing a new mechanism to receive comments and complaints from employees and customers about the banking services provided, in order to develop appropriate solutions and commensurate with the global developments on banking services.

- The researcher recommend the scholars and interested researchers to conduct further studies and researches that show the importance and advantages of applying BSC approach to banks and Islamic institutions especially as they live in conditions of global competition and need to continuously improve banking services to meet the needs of their clients in accordance with the provisions of Islamic law.

\section{References}

Abbadi, M. R. (2002). A Proposed Framework for Evaluating the Performance of Industrial Establishments in Light of the Modern Manufacturing Environment: A Test Study, Journal of Commercial Studies and Research, Benha University, 22(2).

Abu Fadda, M. (2006). Towards Developing a Balanced score card approach for Measuring Strategic Performance in Islamic Banking Institutions, unpublished PhD Thesis, Arab Academy for Banking and Financial Sciences, Amman, Jordan.

Abu Qamar, M. (2009). Evaluation of the Performance of the Bank of Palestine Limited using Balanced Scorecard, Master Thesis, Islamic University, Gaza, Palestine. 
Abu-Gazer, H. A. (2012). The extent of the use of Balanced Scorecard as a tool for evaluating the performance of the Palestinian Islamic Bank: a field study, unpublished Master Thesis, Faculty of Commerce, Islamic University, Gaza, Palestine.

Ahmad, Z. (2010). The awareness of specialists in the banking business with the BSC approach and the extent to which the commercial, Islamic and foreign banks working in Pakistan have implemented this approach, Interdisciplinary Journal of Contemporary Research in Business Company, Institute of Interdisciplinary Business Research, 2(2).

Al-Dhibeh, Z. (20II). The Extent of Implementation of Balanced score card (BSC) in Yemeni Commercial Banks: An Empirical Study on Yemeni Commercial Banks, Economic and Administrative Research , 9.

Al-Gareeb \& Abu Ajila R. (2012). The extent of the possibility of using a balanced sceore card to evaluate performance in Libyan commercial banks, unpublished Master thesis, Middle East University, Business School.

Ali, A. M. (2005). Hedging the Risks of Financing Formats: The Sudan Experience, Joumal of the Union of Arab Banks, 299, 54-58.

Al-Najjar, S. M., \& Khalaf K. H. (20I2). Designing a Balanced Scorecard to Measure a Bank's Performance: A Case Study, International Journal of Business Administration, 3(4).

Azaizia, S. (2010). Constraints on the Use of Balanced Scorecard in Jordanian Commercial Banks, Unpublished Master Thesis, Al-Bayt University, Jordan.

Barkman, H. N. (2007). Using the Balanced Scorecard as a New Technique for Strategic Control in Practice on Some Business Organizations, unpublished $\mathrm{PhD}$ thesis, Damascus, 87-88.

Chaudran, D. (2003). Balanced Scorecard (BSC) and performance improvement, http//Organized Chang.com/Balance Scorecard.htm.

Dargham, M., \& Abufadda, M. (2009). The Effect of the Balanced Performance Model(BSC) on Enhancing the Strategic Financial Performance of the Palestinian National Banks Operating in the Gaza Strip, Journal of the Islamic University, I7(2), 74I-788.

Dave, S. R. (2012). Applaying Balanced Scorecard in Indian Banking Sector: An Empirical study of the state bank of India, Pacific Business Review International, 5(6).

Kaplan, R., \& David, N. (I992). The Balanced Scorecard Measure the Drive performance, Harvard business review, I7O(I).

Moriswa, T. (2002). Building performance measurement systems with the balance score card Approach, Nomura Research Institute (NAI) papers, No.45, April.

Mubarak, A. M., Younis \& Mohamed M. (1996). Economics of Money, Banking and International Trade, University House, Alexandria, p. 173.

Nik, M. N. A., Abdul., A. R. H., \& Abdul H. A. (2013). The Balanced Scordcard: Structure and Potential Use in Malaysian Islamic Banks, The 5th International Conference on Financial Crime (ICFC), Global Trends in Financial Crimes in the New Economies.

Ombuna, D. S., Omido, K., Garashi, H. M., Odera, O., \& Okaka, O. (2013). Impact of balanced scorecard usage on the performance of commercial banks. International Journal of Information Technology and Business Management, IO(I), 40-48.

Rostami, M., Goudarzi, A., \& Zaj, M. (2015). Defining balanced scorecard aspects in banking industry using FAHP approach. International Journal of Economics and Business Administration, $I(\mathrm{I}), 25-38$.

Salama, R. (2002). Motives of Traders with Commercial and Islamic Banks in Jordan, Al-Busair Magazine, 6(2),12-42.

Salamat S., \& Ghadikalaei, S. M. H. (2014). Evaluate performance of employee in Bank based on BSC Balanced Scorecard Model (case study: branches of Tehran district), Epistemologia, II(2), 238-244.

Zhang, Y., \& Li, L. (2009). Study on Balance Scorecard of Commercial Bank in Performance Management System ,Proceeding of the 2009, International Symposium on Web Information Systems and Applications (WISA09) Nanchang, P.R.Chaina, May 22-24,pp206-209.

Zoelf , A., \& Noor, A. N. (2005). The Importance and Extent of the Use of Balanced Scorecard in Evaluating Performance: An Applied Study in a Sample of Jordanian Banks, Jordanian Journal of Business Administration, I(2), I8-39. 


\title{
Appendix
}

Questionnaire

My dear brother

The researcher is preparing a research entitled "The reality of applying the balanced score card approach and the obstacles to its application in the Islamic banks operating in the Hebron governorate." This is a set of measures that include the following dimensions (financial dimension, after customers, after internal processes), After education and growth, the social dimension, after the controls of legal transactions) to measure the extent of application of Islamic banks in all banking transactions.

As an employee of Islamic banks, and to the importance of your opinion, which will enrich the research, please answer all the paragraphs of this questionnaire accurately and objectively, knowing that this information will be treated in strict confidence and will be used only for the purposes of this research.

With high respect and appreciation

Researcher

Raed Ahmed Abueid

First: Personal data : Please answer the following questions by selecting the appropriate sentence

\section{Sex}
a. Male
b. Female

\section{Academic Qualifications}

a. Secondary stage b. Diploma c. Bachelor d. Postgraduate

\section{Bank in which you work}

.a. Islamic Arab Bank b. Bank Islamic Palestinian

\section{Branch of the bank in which you work}

\author{
a. Arab Yatta \\ b.Arab Hebron \\ c. Wadi al-Tuffah Palestinian \\ d. Ras al-Joura Palestinian
}

\section{Job title}

a. Branch Manager b. Observer c. Administrative Employee d. Head of Department

Second : Basic Data:

The first section: the reality of the implementation of BSC approach in Islamic banks: This approach consists of six dimensions: 
First dimension :Financial dimension: Please mark $(\sqrt{ })$ in the corresponding field for each paragraph:

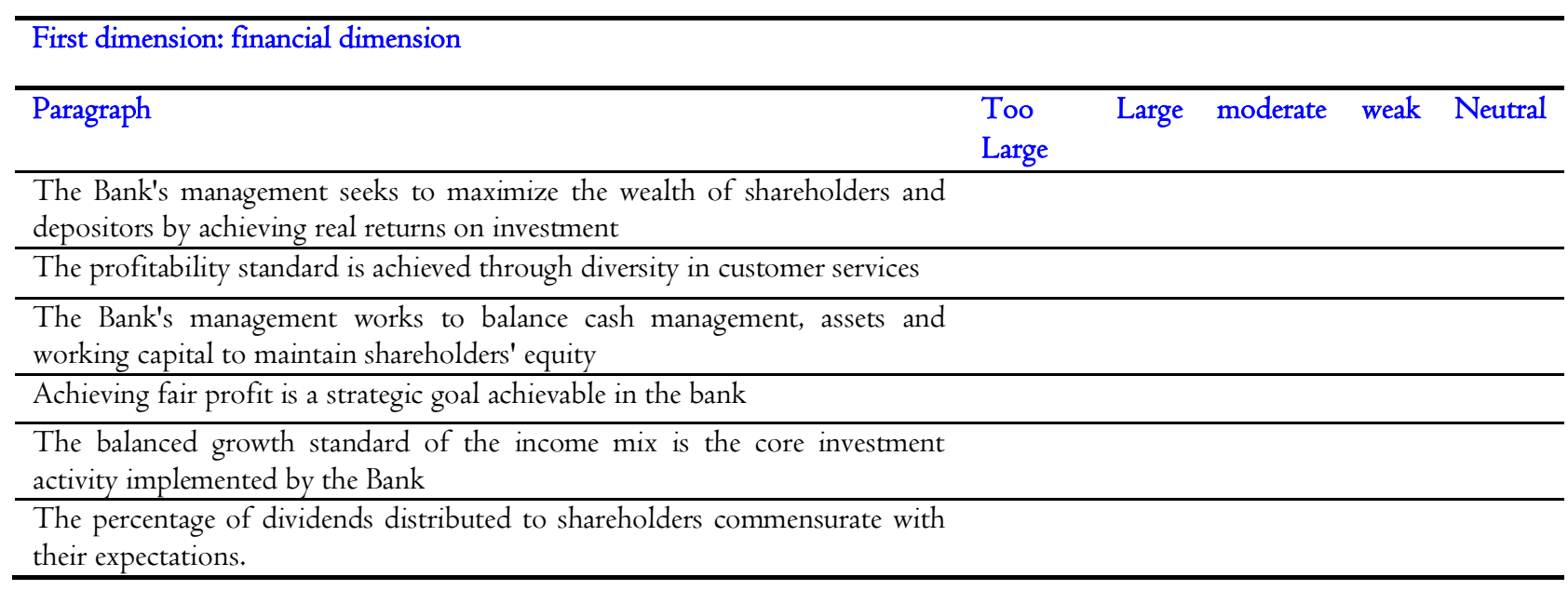

Second dimension : customers dimension: Please mark $(\sqrt{ })$ in the corresponding field for each paragraph:

\section{Second dimension: customers dimension}

\begin{tabular}{|c|c|c|c|}
\hline Paragraph & $\begin{array}{l}\text { Too } \\
\text { Large }\end{array}$ & weak & Neutral \\
\hline \multicolumn{4}{|l|}{$\begin{array}{l}\text { The Bank applies the customers retention standard by increasing the volume } \\
\text { of transactions and communicating with them continuously. }\end{array}$} \\
\hline \multicolumn{4}{|l|}{$\begin{array}{l}\text { Customers loyalty is obtained through the provision of banking services in the } \\
\text { shortest possible time and response to the treatment of customers complaints. }\end{array}$} \\
\hline \multicolumn{4}{|l|}{$\begin{array}{l}\text { The time spent providing the service is commensurate with the normal time of } \\
\text { the service. }\end{array}$} \\
\hline \multicolumn{4}{|l|}{$\begin{array}{l}\text { The Bank applies the fair market share standard, which balances the available } \\
\text { regulatory capacity with the target market share. }\end{array}$} \\
\hline \multicolumn{4}{|l|}{$\begin{array}{l}\text { The Bank practices the standard of profitability of the client through } \\
\text { achieving a fair and satisfactory profit for him. }\end{array}$} \\
\hline \multicolumn{4}{|c|}{$\begin{array}{l}\text { The Bank maintains a customer's retention standard through the number of } \\
\text { customers who have left the Bank. }\end{array}$} \\
\hline \multicolumn{4}{|c|}{ Third dimension : Internal processes dimension: Please mark $(\sqrt{ })$ in the corresponding field for each paragraph: } \\
\hline \multicolumn{4}{|l|}{ Third Dimension: internal processes dimension } \\
\hline Paragraph & $\begin{array}{l}\text { Too Large moderate } \\
\text { Large }\end{array}$ & weak & Neutral \\
\hline \multicolumn{4}{|l|}{$\begin{array}{l}\text { The Bank is always seeking to develop and improve the services, staff skills } \\
\text { and information technology of the Bank. }\end{array}$} \\
\hline \multicolumn{4}{|l|}{$\begin{array}{l}\text { The standard of mastering and providing the service applied in the bank } \\
\text { competes with global standards. }\end{array}$} \\
\hline \multicolumn{4}{|l|}{$\begin{array}{l}\text { The Bank practices the standard of productivity by meeting the needs of } \\
\text { customers, which makes the service of a desirable quality. }\end{array}$} \\
\hline $\begin{array}{l}\text { The Bank applies the efficiency standard in the treatment of available } \\
\text { resources, which determines the level of utilization of available capacity. }\end{array}$ & & & \\
\hline
\end{tabular}


Forth dimension : learning and growth dimension : Please mark $(\sqrt{ })$ in the corresponding field for each paragraph:

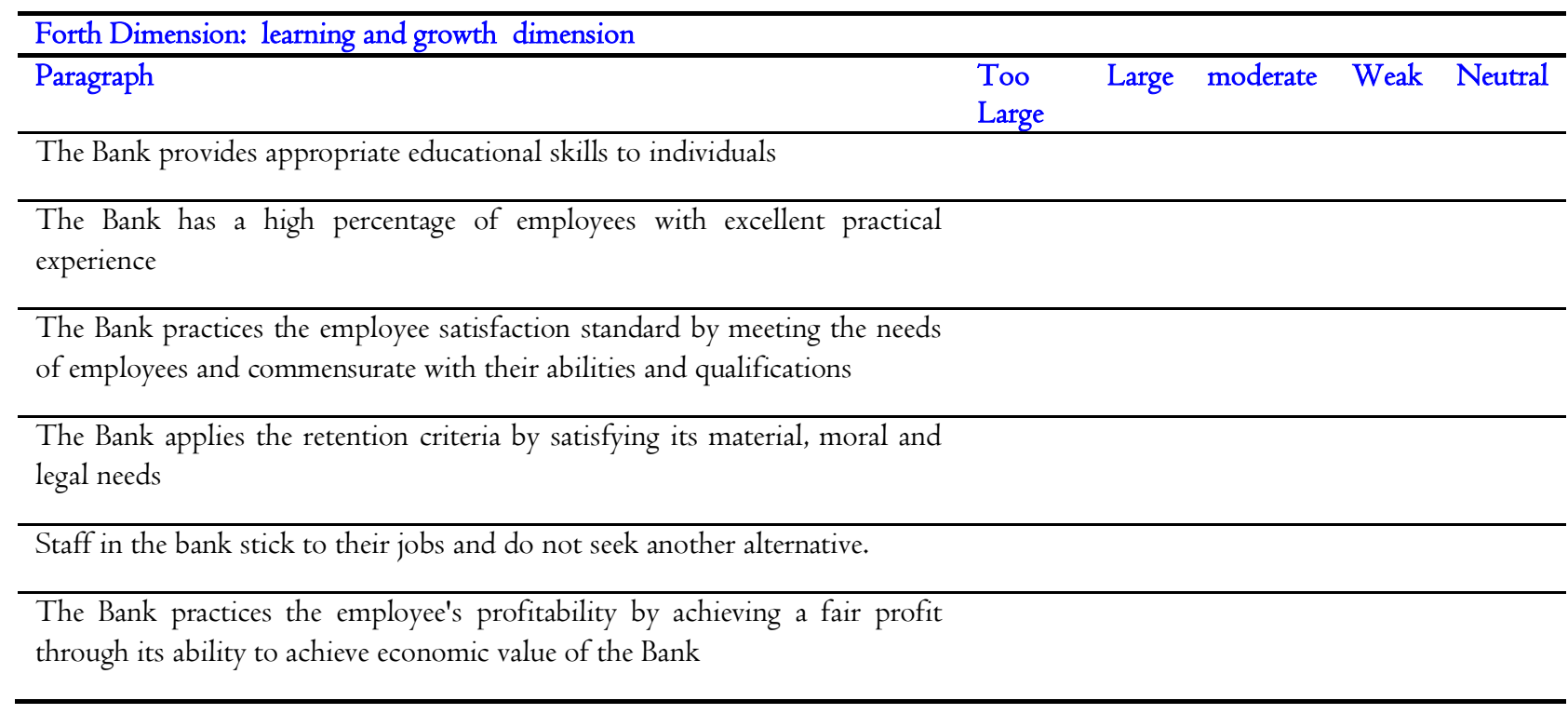

Fifth dimension : social dimension : Please mark $(\sqrt{ })$ in the corresponding field for each paragraph:

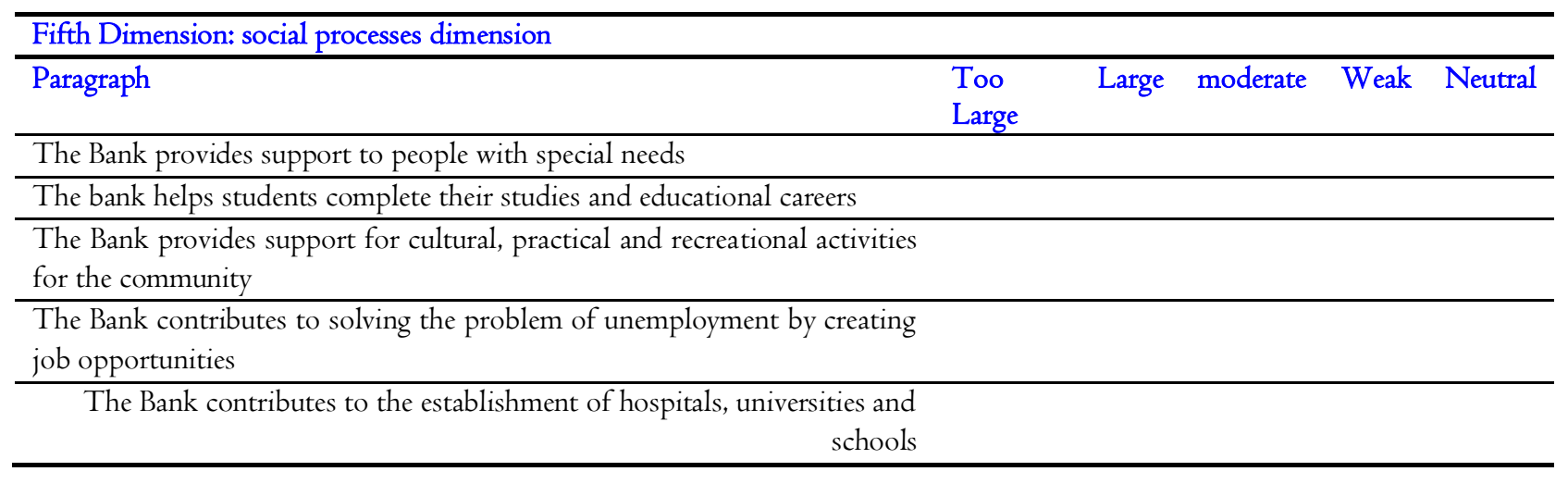

Sixth dimension : the controls of legal transactions dimension: Please mark $(\sqrt{ })$ in the corresponding field for each paragraph:

\begin{tabular}{lll}
\hline Sixth Dimension: the controls of legal transactions dimension & & Too \\
\hline Paragraph & Large & \\
\hline The bank avoids dealing with riba taking and giving & \\
\hline $\begin{array}{l}\text { The Shari'ah Supervisory Board ensures that the Bank complies with its legal } \\
\text { obligations in all banking transactions }\end{array}$ & \\
\hline
\end{tabular}

The Bank applies the principle of good morals in dealing with employees and customers 
Banking operations conducted at the bank are free of illicit sales

The Bank applies the rules and standards prescribed by the Audit and Auditing Organization for Islamic Financial Institutions

Second section: Obstacles to the implementation of the BSC approach in Islamic banks

\begin{tabular}{lll}
\hline Paragraph & $\begin{array}{l}\text { Too } \\
\text { Large }\end{array}$ & Large moderate Weak Neutral \\
\hline
\end{tabular}

The Bank does not know the advantages of applying the BSC Approach

The cost of implementing this approach is high

Lack of financial resources to implement this approach

The complexity of the system applied in the bank prevents the application

of this approach

The inability to keep pace with the technological developments in this approach

Lack of willingness of employees in the bank to change

Lack of competencies capable of compiling and analyzing data to

implement this approach

\section{Copyrights}

Copyright for this article is retained by the author(s), with first publication rights granted to the journal. This is an open-access article distributed under the terms and conditions of the Creative Commons Attribution license (http://creativecommons.org/licenses/by/4.0/). 